Editorial

doi:10.3991/ijep.v1i2.1634

\title{
Eleonore Lickl
}

Engineering Pedagogy is a topic which is important to millions of students in engineering fields worldwide. We all know what engineering is, but from where does the knowledge come, which is necessary that engineering can perform all its tasks? Basics are physics and chemistry, followed by any discipline whatever the topic given needs. Engineering pedagogy is also a topic which is important to the employers of the future engineers and to the economic outcome in large. The engineering pedagogy of their engineering educators forms and educates them.

Do we need more - more Engineering Pedagogy?

Curricula development is a worldwide topic, too. Any discussion about curricula development is important - what should a future engineer have been taught he or she can work with in his or her profession? Engineering pedagogy is mostly not in the focus, although the performance of engineers depends on the engineering education they have received. In this issue of the International Journal of Engineering Pedagogy Vol. 1, No 2 (2011) we try to open a discussion on engineering ethics, learning environments and project work and management.

A view on a critical dimension of the engineering profession, the engineering ethics is given by Nael Barakat [1]. The importance of ethics for the engineering profession is shown in the interactions with the public: Barakat stresses the importance of engineering on human health and welfare. But unfortunately, engineering appears in the media mostly only when disaster occurs - as f. e. in March 2011 during the Japanese earthquake followed by a tsunami and the problems concerning the nuclear power plants of Fukushima Dai. Natural disasters have been occurred. At the moment, June 2011, gut bacteria rule us all in Europe, an entero-hemorrhagic Escherichia coli. The genus exists since Theodor Escherich described it already in 1885, having it found in the human gut [2]. This genus can be deadly dangerous to human, when it is appearing in the "enterohemorrhagic" form in its sense, with internal bleeding from the uremic system. But this bacteria is of "natural" origin. Nevertheless, media and the public are looking for a culprit, possibly an engineer.

One could conclude: have any man made disaster - politicians, media and the public blame the engineer. Therefore it is necessary that engineers can cope with media. (To scope with politicians is another topic which is to far away from us, again, according to my personal opinion). It is thought that engineers have to understand the dimensions and impact of the profession, the need for ethics to protect the engineer and the profession, and, of course, the public.

We encourage prospective authors to continue this topic of engineering ethics and engineering ethic education. Personally, I am not convinced that we are doing the only possible action when we introduce professional ethics into the curricula. Engineers work along rules, rules given by natural laws to have anything going at all first, but they work also along rules given by legislation, national and or international regulations, specifications and more. Would it not be wise to give the future engineer firstly more knowledge about legislation and secondly more knowledge about media, how media is functioning, to give them a better stand against politicians and against the public?

Learning is an important topic in pedagogy, and in engineering pedagogy. Ramollari et al [3] discuss in their paper aspects of collaborative learning in different learning environments. Their 
learning environment in the automobile sector uses a set of resources on the modeling languages UML and SysML, and on web 2.0 tools.

Phillip Sanger describes in his article "Integrating Project Management, Product Design with Industry Sponsored Projects provides Stimulating Senior Capstone Experiences" [4] that "many students are uncomfortable with real world engineering problems where needs and requirements must be concretely defined and the selection of design solutions is not black and white". He describes a two semester course for students from three Engineering and Technology Department programs (electrical engineering, electrical and computer engineering technology, and engineering technology) that brings together the tools of project management and the creative product development process into industry sponsored projects. "The projects have been undertaken with students getting an exciting authentic life experience and introducing them to the real world of engineering". Does that include the world of politics and the media?

Once again, the real world of engineering is mentioned, we encouraged all authors who have experience in the "real world of engineering" to contribute to this journal. We are looking forward to your examples on all topics of engineering pedagogy.

An example from the practical world of civil engineering is given in the paper of Igić and Veljković [5]. The problem of monitoring of civil engineering structures and constructions is discussed and a system, called "Civil Engineering Structures Reliability" is proposed.

ILAN - a report about an Innovative Language Training Course: English for Students, Lecturers and Administrators of Technical Universities, editors: A. Alipichev, N. Bogoroditskaya, A. Galiguzova, E. Dvoretskaya, G. Kosova, T. Polyakova, I. Shelenkova, and E. Shchaveleva was reviewed by I. Šimonová [6]

\section{REFERENCES}

[1] N. Barakat, "Engineering Ethics: A Critical Dimension of The Profession" Int. Journal of Engineering Pedagogy 1, 2, pp. $24-28,2011$. doi:10.3991/ijep.v1i2.1639

[2] Th. Escherich, "Die Darmbakterien des Neugeborenen und Säuglings" Fortschritte der Medizin 3, 16, 515-522 and 547-554, 1885.

[3] E. Ramollari, M. Heintz, S. Weber, S. Trapp, D. Dranidis and J. Börstler, "Collaborative Learning of UML and SysML" Int. Journal of Engineering Pedagogy 1, 2, pp. 6-12, 2011. doi:10.3991/ijep.v1i2.1663

[4] P. Sanger, "Integrating Project Management, Product Design with Industry Sponsored Projects provides Stimulating Senior Capstone Experiences" Int. Journal of Engineering Pedagogy 1, 2, pp. 13-18, 2011. doi:10.3991/ijep.v1i2.1682

[5] T. S. Igić and N. Ž. Veljković, "Design of a System for Monitoring Reliability of Structures and Constructions in Civil Engineering" Int. Journal of Engineering Pedagogy 1, 2, pp. 19-23, 2011. doi:10.3991/ijep.v1i2.1634

[6] ILAN - Innovative Language Training Course, English for Students, Lecturers and Administrators of Technical Universities, A. Alipichev, N. Bogoroditskaya, A. Galiguzova, E. Dvoretskaya, G. Kosova, T. Polyakova, I. Shelenkova, E. Shchaveleva reviewed by I. Šimonová, Int. Journal of Engineering Pedagogy 1, 2, pp. 29-30, 2011. doi:10.3991/ijep.v1i2.1634

\section{Dr. Eleonore Lickl}

Editor-in-Chief

HBLVA fuer chemische Industrie

Rosensteingasse 79

A-1170 Wien, Austria

eleonore.lickl@schule.at 